\title{
MENINGKATKAN PARTISIPASI PEMILIH MELALUI KOMUNIKASI POLITIK
}

\author{
L. M. Azhar Sa'ban ${ }^{1}$, Andy Arya Maulana Wijaya ${ }^{2}$, La Doli $^{3}$ \\ 1,2,3 Program Studi Ilmu Pemerintahan, Universitas Muhammadiyah Buton \\ Email: izharrazi@gmail.com
}

\begin{abstract}
The purpose of this study (1) is to explain how the level of political participation of the community in the 2018 Regional Election in Baubau City (2) to identify any efforts made by the Baubau City Election Commission and political parties in increasing public political participation. Data were collected by analyzing documents, observing, interviewing, and analyzing with qualitative and quantitative descriptive techniques. The results of this study are: (1) The level of community participation in Baubau City is relatively high because if it is accumulated at $69.87 \%$. (2) KPUD communication to increase public political participation is to use mass media to create society following the development of the Election process. (3) Communication of Political Parties to increase political participation of the community is this political campaign is a form of political communication carried out by a person or group of people or political organizations in a certain time to obtain political support from the people.
\end{abstract}

Keywords: Political Communication, Political Participation, Regional Elections Baubau City

\begin{abstract}
Abstrak: Tujuan penelitian ini adalah untuk menjelaskan bagaimana tingkat partisipasi politik masyarakat dalam Pemilihan Kepala Daerah tahun 2018 di Kota Baubau, serta mengidentifikasi upaya-upaya apa saja yang dilakukan KPUD Kota Baubau dan partai politik dalam meningkatkan partisipasi politik masyarakat. Data dikumpulkan dengan analisis dokumen, pengamatan, wawancara, dan dianalisis dengan tehnik deskriptif kualitatif dan Kuantitatif. Hasil dari penelitian ini adalah tingkat partispasi masyarakat di Kota Baubau tergolong tinggi dikarenakan jika diakumulasikan sebesar 69,87\% \%, komunikasi Komisi Pemilihan Umum Daerah (KPUD) Kota Baubau untuk meningkatkan partisipasi politik masyarakat adalah menggunakan media massa untuk menciptakan masyarakat mengikuti perkembangan proses Pemilu, dan Komunikasi Partai Politik untuk meningkatkan partisipasi politik masyarakat adalah kampanye politik ini merupakan bentuk komunikasi politik yang dilakukan oleh seseorang atau sekelompok orang atau organisasi politik dalam waktu tertentu untuk memperoleh dukungan politik dari rakyat.
\end{abstract}

Kata Kunci: Komunikasi Politik, Partisipasi Politik, Pemilukada Baubau

\section{PENDAHULUAN}

Pemilihan Kepala Daerah merupakan wujud dari pembentukan demokratisasi di daerah. Pemilihan kepala daerah dan wakil kepala daerah di pilih dalam satu pasang calon yang dilaksanakan secara domokratis, secara langsung dipilih oleh penduduk daerah administratif setempat yang memenuhi syarat, berdasarkan asas langsung, umum, bebas, rahasia, jujur dan adil. Manakala Pemilihan Kepala Daerah (PILKADA) memang diakui secara global, sebagai sebuah arena untuk membentuk demokrasi perwakilan serta menggelar pergantian pemerintahan secara berkala (Anugrah, 2017).

Tujuan utama PILKADA adalah rakyat daerah bisa menentukan sendiri orang tertentu yang dianggap atau dinilai mampu membawa kebaikan bagi seluruh rakyat di daerah tersebut. Pemilihan Kepala Daerah secara langsung dinilai sebagai sarana dan cermin atas hak dasar kedaulatan rakyat dengan memberikan kewenangan yang utuh dalam melaksanakan serta menentukan pimpinan daerah untuk mewujudkan demokrasi tingkat lokal. Menurut teori demokrasi minimalis dari Schumpeterian, 
PILKADA merupakan sebuah arena yang mewadahi kompetisi atau kontestasi antara aktor politik untuk meraih kekuasaan; partisipasi politik rakyat untuk menentukan pilihan; serta liberalisasi hakhak sipil dan politik warga negara (Liando, 2016).

Gerakan reformasi setidaknya membawa tiga perubahan paling mendasar dalam sistem pemilihan umum di Indonesia. Pertama; kembalinya sistem multi-partai seperti tahun 1955 dari sebelumnya hanya tri-partai di masa orde baru. Kedua; sesuai dengan Peraturan Pemerintah Nomor 6 tahun 2005 tentang Pemilihan, pengesahan pengangkatan dan pemberhentian Kepala Daerah dan Wakil Kepala Daerah sesuai dengan yang diamanatkan oleh Undang-Undang No. 32 tahun 2004, dan Ketiga, sejak tahun 2004 dilakukan dua kali memilih wakil-wakil rakyat melalui Pemilu legislatif dan selanjutnya Pemilu Presiden secara langsung (Suherman, 2019).

Pengajuan pasangan calon Kepala Daerah bisa dilakukan oleh partai politik atau gabungan partai politik yang memiliki kursi di DPRD dengan persyaratan tertentu dan/atau dari calon perseorangan dengan persyaratan tertentu pula. Dibutuhkan suatu pilihan yang tepat oleh rakyat terhadap pasangan Kepala Daerah sehingga dapat dihasilkan pasangan Kepala Daerah yang memiliki visi meningkatkan kesejahteraan rakyat daerah (Widodo, 2015).

Berdasarkan pendapat diatas, maka pada hakikatnya pilkada merupakan sebuah peristiwa luar biasa yang dapat membuat perubahan berarti bagi daerah. Ini merupakan suatu cara dari kedaulatan rakyat yang menjadi asensi dari demokrasi. Oleh karena itu, asensi dari demokrasi yang melekat pada pilkada hendaknya di sabut masyarakat secara sadar dan cerdas dalam menggunakan hak politiknya.

Pengajuan pasangan calon Kepala Daerah bisa dilakukan oleh partai politik atau gabungan partai politik yang memiliki kursi di DPRD dengan persyaratan tertentu dan/atau dari calon perseorangan dengan persyaratan tertentu pula. Dibutuhkan suatu pilihan yang tepat oleh rakyat terhadap pasangan Kepala Daerah sehingga dapat dihasilkan pasangan Kepala Daerah yang memiliki visi meningkatkan kesejahteraan rakyat daerah (Widodo, 2015).

Harapan besar mengenai implikasi Pilkada langsung ini, rakyat berharap dapat mengetahui dan memahami isi yang terkandung dalam undang-undang, sehingga lebih dapat meningkatkan pengetahuan serta wawasan politik atau pendidikan politik yang lebih dewasa terutama lebih memperhatikan aspek-aspek hubungan antar susunan pemerintahan dan antar pemerintah daerah. Implikasi lebih lanjut melalui pemahaman undang-undang tersebut akan membuat rakyat menjadi paham politik, membangun tingkat kesadaran dalam berpolitik, serta masyarakat lebih kreatif dalam memilih calon kepala daerah yang mempunyai pemikiran yang ingin membangun daerahnya untuk maju dan sejahtera serta pelayanan publik yang lebih baik (Selatan \& Sitaro, 2013).

Pelaksanaan Pemilihan Kepala Daerah secara langsung dan serentak di Indonesia diselenggarakan oleh Komisi Pemilihan Umum Daerah (KPUD) dan diawasi oleh Badan Pengawas Pemilu untuk tingkat provinsi dan Panitia Pengawas Pemilihan Kabupaten/Kota untuk tingkat Kabupaten/Kota (Sianturi \& Wisnaeni, 2016)

Ajang pemilihan kepala daerah serentak telah berlangsung pada tanggal 27 Juni 2018, salah satu daerah yang mengikuti pesta demokrasi dalam pilkada serentak tahun 2018 adalah Kota Baubau. Berdasarkan proses pendaftaran calon yang dilaksanakan sesuai dengan tahapan, Komisi Pemilihan Umum Kota Baubau menetapkan lima pasangan calon Walikota dan Wakil Walikota Baubau, nomor urut 1 pasangan calon $\mathrm{Hj}$. Roslina - La Ode Yasin partai pengusung Hanura dan PKB, nomor urut 2 pasangan DR. H. A.S. Tamrin, M.H - La Ode Ahmad Monianse partai pengusung PAN, PDIP, Nasdem dan Golkar, nomor urut 3 pasangan $\mathrm{Hj}$. Wa Ode Maasra Manarfa, S.Sos., M.Si - Ikhsan Ismail partai pengusung PBB dan Gerindra, nomor urut 4 pasangan H. Yusran Fahim, SE - Drs. H. 
JISIP: Jurnal Ilmu Sosial dan Ilmu Politik

ISSN. 2442-6962

Vol. 9 No. 2 (2020)

Ahmad, MM partai pengusung Demokrat, PPP dan PKS, nomor urut 5 pasangan Drs. H. Ibrahim Marsela, M.M - Ilyas, S.Sos calon perseorangan dengan jumlah dukungan sebanyak 11.642 KTP (KPUD Kota Baubau).

Masyarakat sebagai aktor utama dalam pemilihan ini dituntut agar lebih partisipatif dalam segala bentuk tahapan penyelenggaraan pemilihan umum kepala daerah. Jumlah pemilihan Kota Baubau dapat dilihat pada tabel berikut:

Tabel 1. Rekapitulasi data pemilih

\begin{tabular}{|c|l|c|c|}
\hline No & Kecamatan & Jumlah Pemilih & Tingkat Partisipasi Pemilih \\
\hline $\mathbf{1}$ & Betoambari & 12.979 & 9.325 \\
\hline $\mathbf{2}$ & Batupoaro & 20.495 & 14.248 \\
\hline $\mathbf{3}$ & Murhum & 13.656 & 10.462 \\
\hline $\mathbf{4}$ & Wolio & 30.722 & 20.258 \\
\hline $\mathbf{5}$ & Bungi & 5.206 & 4.540 \\
\hline $\mathbf{6}$ & Sorawolio & 5.220 & 3.829 \\
\hline $\mathbf{7}$ & Kokalukuna & 13.308 & 9.997 \\
\hline $\mathbf{8}$ & Lea-Lea & 5.368 & 4.162 \\
\hline \multicolumn{2}{|c|}{ Jumlah } & 106.954 & 76.821 \\
\hline
\end{tabular}

Sumber: KPUD Kota Baubau Tahun 2018

Salah satu faktor pendukung pemilihan umum kepala daerah adalah tingkat partisipasi yang masyarakat, jumlah partisipasi yang tinggi akan menunjukan kesadaran masyarakat tentang pentingnya pemilihan umum kepala daerah. Dari tabel diatas menjelaskan bahwa masih belum maksimal partisipasi politik masyarakat dalam kegiatan Pemilihan Kepala Daerah di Kota Baubau, dapat dilihat dari masih banyaknya masyarakat yang tidak menggunakan hak pilihnya, dengan berbagai alasan dan penyebab yang berbeda-beda. Berdasarkan uraian tersebut, penulis tertarik untuk melakukan penelitian dengan jidul Partisipasi Politik Masyarakat dalam Pemilihan Kepala Daerah Kota Baubau Tahun 2018.

Partisipasi politik masyarakat merupakan bentuk perwujudan negara demokrasi, dimana masyarakat dilibatkan langsung dalam Pemilihan Umum. Dalam hal ini, warga negara berperan penting dalam menseleksi pejabat-pejabat negara yang nantinya akan mengatur pemerintahan maupun tindakan-tindakan yang akan mereka ambil nantinya (Suryadi, 2007).

Bahwa semua warga negara memiliki peluang dan kesempatan yang sama dalam mengevaluasi dan menentukan pemimpinnya, sehingga partisipasi politik, dalam hal ini keikutsertaan warga negara dalam PILKADA, menjadi penting. Pada sisi yang sama, pemahaman yang baik terhadap peran-peran strategis warga negara juga akan mendorong kualitas demokrasi (Liando, 2016).

Partisipasi politik dapat bermanfaat untuk: (1) memberikan dukungan kepada penguasa dan pemerintah dalam bentuk pengiriman wakil atau pendukung, pembuatan pernyataan yang isinya memberikan dukungan terhadap pemerintah, dan pemilihan calon yang diusulkan oleh organisasi politik; (2) menunjukan kelemahan dan kekurangan pemerintah dengan harapan agar pemerintah meninjau kembali, memperbaiki, atau mengubah kelemahan tersebut; (3) partisipasi sebagai tantangan terhadap penguasa supaya terjadi perubahan struktural dalam pemerintahan dan dalam sistem politik (Syamsudin Haris, 2014).

Untuk meningkatkan partisipasi politik di perlukan komunikasi politik. Komunikasi sebagai esensi dari interaksi antar manusia memegang peranan penting dalam semua aspek kehidupan, 
termasuk politik. Komunikasi politik berperan menyambungkan semua bagian dari sistem politik sehingga aspirasi dan kepentingan tersebut dikonversikan menjadi kebijaksanaan. Karena itu komunikasi politik secara keseluruhan tidak dapat dipahami, kecuali apabila dihubungkan dengan dimensi politik dalam segala aspek dan Komunikasi politik berkaitan erat dengan sistem politik yang dianut sebuah negara. Komunikasi politik, seperti halnya di sisitem politik lainnya juga mutlak diperlukan dalam proses pembentukan pemerintahan. Keikutsertaan rakyat dalam proses pemerintahan diwujudkan melalui adanya penyelenggaraan pemilihan umum (pemilu) (Fauzi, 2018).

\section{METODE PENELITIAN}

Kajian ini merupakan penelitian kepustakaan (library research), dengan menggunakan pendekatan deskriptif dan metode kualitatif (Creswell, 2010). Teknik pengumpulan datanya dilakukan dengan cara memanfaatkan kepustakaan dan penelusuran data online, serta wawancara mendalam pada masyarakat dan tokoh masyarakat di Kota Baubau, yang kompeten menjawab masalah politik (Bushman \& Wells, 2001).

Data penelitian kemudian dianalisis dengan teknik analisis data kualitatif, yang tahapannya terdiri dari reduksi data atau data reduction; penyajian data atau data display; dan penarikan kesimpulan atau conclusion drawing (Bloor, 1997).

\section{HASIL DAN PEMBAHASAN}

\section{Tingkat Partisipasi Politik Mayarakat dalam Pelaksanaan Pemilihan Kepala Daerah Kota Baubau Tahun 2018}

Pada tanggal 27 Juni 2018 ajang pemilihan kepala daerah serentak telah berlangsung di Kota Baubau. Masyarakat Kota Baubau mengadakan Pemilihan Kepala Daerah, dimana ditemukan presentase tingkat partisipasi pemilih mencapai $69,87 \%$ dan sisanya $30,13 \%$ adalah masyarakat yang tidak menggunakan hak pilihnya.

Dari persentase perolehan suara diatas dapat diketahui bahwa tingkat partisipasi masyarakat Kota Baubau pada saat Pemilihan Kepala Daerah tahun 2018 tergolong cukup tinggi.

Dalam meraih demokrasi, partisipasi politik merupakan unsur penting yang harus ada dalam setiap pemilihan Kepala Daerah. Kebebasan dalam mengeluarkan pendapat dan memilih suatu calon mutlak harus ada didalam suatu Negara yang bercirikan demokrasi didalamnya, tak terkecuali di Indonesia. Adanya kebebasan rakyat dalam menjalankan partisipasi politik menjadi tolak ukur untuk melihat eksistensi demokrasi dalam suatu Negara.

Dari hasil temuan penelitian faktor-faktor yang mempengaruhi partisipasi politik masyarakat pada Pemilihan Kepala Daerah di Kota Baubau pada tahun 2018 adalah (1). Faktor Perangsang Politik (2). Faktor Karakteristik Pribadi (3). Faktor Karakteristik Sosial (4). Faktor Keadaan Politik. Pelaksanaan Partisipasi politik masyarakat tentu saja tidak berlangsung tanpa adanya faktor - faktor pendukung, tentu saja banyak hal yang sangat mempengaruhi pelaksanaan partisipasi politik masyarakat.

\section{Komunikasi Partai Politik dalam Meningkatkan Partisipasi Pemilih}

Partai politik merupakan perantara yang besar yang menghubungkan kekuatan-kekuatan dan ideologi-ideolgi sosial dengan lembaga pemerintah yang resmi dan yang mengkaitkannya dengan aksi politik dalam masyarakat yang lebih luas. Berdasarkan pandangan tersebut, partai menekankan pentingnya kampanye politik yang dilakukan oleh partai politik untuk memperkenalkan para calegnya. 
Kampanye politik adalah bentuk komunikasi politik yang dilakukan oleh seseorang atau sekelompok orang atau organisasi politik dalam waktu tertentu untuk memperoleh dukungan politik dari rakyat.

Partai politik berperan penting dalam mendorong partisipasi politik. Selain itu, partai politik juga harus memberikan pemahaman kepada pemilih tentang arti pentingnya partisipasi masyarakat dalam pemilihan umum kepala daerah untuk meningkatkan kompetensi masyaraakat untuk ikut dalam kompetisi politik dan meminimalisir kendala dalam pelaksanaan pendidikan politik yang berujung pada rendahnya partisipasi politik pemilih.

Partai politik melakukan upaya-upaya untuk mengatasi berbagai kendala terhadap pelaksanaan pendidikan politik yang bertujuan untuk meningkatkan partisipasi politik masyarakat. Upaya yang dilakukan diantaranya: partai melakukan pendekatan internal/personal. Partai mengedepankan caracara persuasif untuk menarik hati dan simpati masyarakat guna aktif partisipatif dalam gerak politik. Pendekatan internal dilakukan untuk mengetuk kesadaran masyarakat untuk menyadari peranannya sebagai warga negara yang memiliki hak, kewajiban dan tanggung jawab politik.

Menciptakan masyarakat untuk mengikuti perkembangan proses Pemilu melalui media massa, ini telah menjadi salah satu bentuk sosialisasi kepada masyarakat yang dilakukan oleh partai politik, sehinnga masyarakat tahu dengan pasti tentang proses Pilkada. Terkait dengan peningkatan kinerja penyelenggara Pemilu, bukan hanya terkait dengan kinerja teknis penyelenggaraan, namun juga dalam hal penumbuhan kesadaran tentang pentingnya partisipasi masayarakat dalam penyelenggaraan Pemilu, sehingga masyarakat bisa memahami partisipasi apa saja yang dapat dilakukan dan apa output dari partisipasi tersebut.

Menunjukkan bahwa media baik media televisi, media internet, dan media surat kabar cetak telah dapat dimanfaatkan dengan baik oleh masyarakat sebagai sumber informasi maupun sebagai sarana partisipasi politik.

\section{Komunikasi KPUD dalam Meningkatkan Partisipasi Pemilih}

Dari temuan penelitian, upaya KPU Kota Baubau untuk meningkatkan partisipasi dalam Pemilihan Kepala Daerah Kota Baubau yang berlangsung pada tahun 2018.

Sosialisasi Pemilihan Kepala Daerah hal yang dilakukan adalah memaksimalkan proses sosialisasi tentang pentingnya Pemilu dalam sebuah Negara yang demokratis, bukan hanya sosialisasi teknis penyelenggaraan Pemilu. Meskipun dalam ketentuan undang-undang menyatakan bahwa sosialisasi dilakukan terkait dengan teknis penyelenggaraan Pemilu, namun sosialisasi segala hal yang melatarbelakangi penyelenggaraan Pemilu perlu untuk dilakukan.

Menciptakan masyarakat untuk mengikuti perkembangan proses Pemilu melalui media massa, ini telah menjadi salah satu bentuk sosialisasi kepada masyarakat, sehinnga masyarakat tahu dengan pasti tentang proses Pilkada.

Terkait dengan peningkatan kinerja penyelenggara Pemilu, bukan hanya terkait dengan kinerja teknis penyelenggaraan, namun juga dalam hal penumbuhan kesadaran tentang pentingnya partisipasi masayarakat dalam penyelenggaraan Pemilu, sehingga masyarakat bisa memahami partisipasi apa saja yang dapat dilakukan dan apa output dari partisipasi tersebut.

Dari temuan penelitian, upaya KPUD untuk meningkatkan partisipasi dalam Pemilihan Kepala Daerah Kota Baubau yang berlangsung pada tahun 2018. Penjelasannya sebagai berikut:

1) Sosialisasi Pemilihan Kepala Daerah

Hal yang perlu dilakukan adalah memaksimalkan proses sosialisasi tentang pentingnya Pemilu dalam sebuah Negara yang demokratis, bukan hanya sosialisasi teknis penyelenggaraan pemilu. 
Meskipun dalam ketentuan undang-undang menyatakan bahwa sosialisasi dilakukan terkait dengan teknis penyelenggaraan pemilu, namun sosialisasi segala hal yang melatarbelakangi penyelenggaraan Pemilu perlu untuk dilakukan.

2) Membentuk Relawan Demokrasi

Program relawan demokrasi adalah gerakan sosial yang dimaksudkan untuk meningkatkan partisipasi dan kualitas pemilih dalam menggunakan hak pilih. Program ini melibatkan peran serta masyarakat yang seluas-luasnya dimana mereka ditempatkan sebagai pelopor (pioneer) demokrasi bagi komunitasnya. Relawan demokrasi menjadi mitra KPU dalam menjalankan agenda sosialisasi dan pendidikan pemilih berbasis kabupaten/kota. Bentuk peran serta masyarakat ini diharapkan mampu mendorong tumbuhnya kesadaran tinggi serta tanggung jawab penuh masyarakat untuk menggunakan haknya dalam pemilu secara optimal.

3) Memberikan pendidikan bagi pemilih

Pendidikan bagi pemilih perlu mendapatkan fokus yang jelas. Ini terkait dengan proses segmentasi pendidikan pemilih. Pemilih pemula merupakan segmentasi penting dalam upaya melakukan pendidikan bagi pemilih dan tentunya pendidikan bagi pemilih pemula ini tidak hanya dilakukan ketika masuk usia pilih.

Namun lebih dari itu, pendidikan bagi pemula seyogyanya dilakukan sedini mungkin, sehingga pemahaman tersebut terbangun dan ketika sudah mencapai usia pemilih, para pemilih pemula sudah siap menggunakan hak pilihnya secara cerdas.

4) Peran Media Massa

Menciptakan masyarakat untuk mengikuti perkembangan proses Pemilu melalui media massa, ini telah menjadi salah satu bentuk sosialisasi kepada masyarakat, sehinnga masyarakat tahu dengan pasti tentang proses pilkada.

Terkait dengan peningkatan kinerja penyelenggara pemilihan umum kepala daerah, bukan hanya terkait dengan kinerja teknis penyelenggaraan, namun juga dalam hal penumbuhan kesadaran tentang pentingnya partisipasi masayarakat dalam penyelenggaraan Pemilihan umum kepala daerah, sehingga masyarakat bisa memahami partisipasi apa saja yang dapat dilakukan dan apa output dari partisipasi tersebut. Selain upaya sosialisasi pihak KPUD juga berusaha mempercepat percetakan surat suara agar bisa memenuhi deadline sebelum pilkada dimulai.

Dalam meraih demokrasi, partisipasi politik merupakan unsur penting yang harus ada dalam setiap pemilihan Kepala Daerah. Kebebasan dalam mengeluarkan pendapat dan memilih satu calon mutlak harus ada didalam suatu Negara yang bercirikan demokrasi didalamnya, tak terkecuali di Indonesia. Adanya kebebasan rakyat dalam menjalankan partisipasi politik menjadi tolak ukur untuk melihat eksistensi demokrasi dalam suatu Negara

\section{KESIMPULAN}

Berdasarkan hasil penelitian, dan pembahasan penelitian yaitu yang pertama masyarakat Kota Baubau telah berpartisipasi dalam Pemilihan Kepala Daerah pada tanggal 27 Juni 2018 dalam rangka memilih Walikota dan Wakil Walikota dan berdasarkan data-data yang ada jumlah pemilih di Kota Baubau adalah 106.947, dapat dilihat tingkat partisipasi masyarakat Kota Baubau cukup tinggi presentase jumlah pemilih yaitu 69,87\% (76.821) dan sisanya tindak menggunakan hak pilih 30,13\% (30.133). Temuan penelitian kedua yaitu dibalik presentase tingkat partisipasi masyarakat yang tinggi tentu saja ada faktor-faktor yang mempengaruhi tingkat partisipasi politik masyarakat Kota Baubau.

Dibalik tingginya partisipasi politik Pemilihan Kepala Daerah ada dua lembaga yang memiliki peran meningkatkan partisipasi menggunakan komunikasi kepada pemilih yaitu KPU Kota Baubau dan Partai Politik.

1. Komunikasi Partai Politik dalam Meningkatkan Partisipasi Pemilih. 
JISIP: Jurnal Ilmu Sosial dan Ilmu Politik

ISSN. 2442-6962

Vol. 9 No. 2 (2020)

Partai politik memiliki penting dalam meningkatkan partisipasi politik pemili. Selain itu, partai politik juga harus memberikan pemahaman kepada pemilih tentang arti pentingnya partisipasi masyarakat dalam pemilihan umum kepala daerah untuk meningkatkan kompetensi masyaraakat untuk ikut dalam kompetisi politik dan meminimalisir kendala dalam pelaksanaan pendidikan politik yang berujung pada rendahnya partisipasi politik pemilih.

Melalui kampanye politik partai politik berkomunikasi kepada pemilih untuk memperoleh dukungan politik dari rakyat. Dengan tingginya dukungan politik dari rakyat akan meningkatkan partisipasi pemilih untuk menggukan hak pilihnya.

2. Komunikasi KPU Kota Baubau dalam Meningkatkan Partisipasi Pemilih.

KPU Kota Baubau merupakan penyelenggara Pemilihan Kepala Daerah. Secara gencar melakukan sosialisasi Pemilihan umum kepala daerah baik kepada masyarakat yang didalamnya ada pemilih pemula. Dimana pemilih pemula membutuhkan pendidikan politik agar mampu menjadi pemilih cerdas di kemudian hari. Untuk meningkatkan partisipasi politik pemilih KPUD menggunakan: komunikasi politik melalui media massa. Rangsangan politik yang berasal dari media massa, karena pada zaman modern seperti ini media massa merupakan sarana informasi yang sangat mudah sekali diakses oleh masyarakat, dan dari ini masyarakat dapat mengetahui informasi dan mengenal siapa saja calon Wali Kota dan Wakil Walikota.

\section{DAFTAR PUSTAKA}

Anugrah. (2017). Permasalahan Anggaran Pengawasan dalam Pemilihan Kepala Daerah Serentak Tahun 2015. Jurnal Bawaslu, 3(1), 79-44.

Bushman, B. J., \& Wells, G. L. (2001). Narrative impressions of literature: The availability bias and the corrective properties of meta-analytic approaches. Personality and Social Psychology Bulletin, 27(9), 1123-1130. https://doi.org/10.1177/0146167201279005

Bloor, M. (1997). Techniques of Validation in Qualitative Research: A Critical Commentary. London: Sage.

Creswell, John W. (2010). Research Design: Pendekatan Kualitatif, Kuantitaif, dan Mixed. Yogyakarta: Pustaka Pelajar, Terjemahan.

Fauzi, N. (2018). Political Communication of Legislative Candidate in Affecting Political Participation in the North Aceh District (Komunikasi Politik Calon Legislatif dalam Memengaruhi Partisipasi Politik Masyarakat di Kabupaten Aceh Utara). Journal Pekommas, 3(1), 63. https://doi.org/10.30818/jpkm.2018.2030107

Haris, Syamsudin, (2014). Partai, Pemilu, dan Parlemen di Era Reformasi. Jakarta: Yayasan Pustaka Obor Indonesia.

Liando, D. M. (2016). PEMILU DAN PARTISIPASI POLITIK MASYARAKAT ( Studi Pada Pemilihan Anggota Legislatif Dan Pemilihan Presiden Dan Calon Wakil Presiden Di Kabupaten Minahasa Tahun 2014 ). Jurnal LPPM Bidang EkoSosBudKum, 3, 14-28. https://ejournal.unsrat.ac.id/index.php/lppmekososbudkum/article/view/17190

Selatan, B., \& Sitaro, K. (2013). PARTISIPASI POLITIK MASYARAKAT DALAM PEMILIHAN UMUM KEPALA DAERAH DI KECAMATAN SIAU BARAT SELATAN KABUPATEN SITARO 1 Oleh: Arther Muhaling 2 ABSTRAK.

Sianturi, B. E., \& Wisnaeni, F. (2016). Program Studi Magister Ilmu Hukum Fakultas Hukum Universitas Diponegoro. PENGUATAN KELEMBAGAAN PANWAS PEMILIHAN DALAM MENYELESAIKAN PELANGGARAN PEMILIHAN KEPALA DAERAH (STUDI KASUS 
JISIP: Jurnal Ilmu Sosial dan Ilmu Politik

ISSN. 2442-6962

Vol. 9 No. 2 (2020)

PENYELESAIAN PELANGGARAN ADMINISTRASI, PIDANA, DAN KODE ETIK PEMILIHAN WALIKOTA DAN WAKIL WALIKOTA SEMARANG TAHUN 2015), 12. http://eprints.undip.ac.id/57101/

Suherman, A. (2019). Strategi Marketing Politik Anggota Legislatif Perempuan Marketing Policy Strategy for Members of Legislative Women in the 2014 Election in the City of. MEDIALOG: Jurnal Ilmu Komunikasi, II(36), 11-21. http://www.jurnalumbuton.ac.id/index.php/Medialog/article/view/150

Suryadi, Budi, (2007). Sosiologi Politik: Sejarah, Definisi dan Perkembangan Konsep. Yogyakarta: IRCiSoD

Widodo, W. (2015). Pelaksanaan Pilkada Berdasarkan Asas Demokrasi Dan Nilai-Nilai Pancasila. Civis, 5(1), 679-691. http://journal.upgris.ac.id/index.php/civis/article/view/629 